\title{
Sustained Release Buccal Tablet Dosage Form
}

National Cancer Institute

\section{Source}

National Cancer Institute. Sustained Release Buccal Tablet Dosage Form. NCI

Thesaurus. Code C69007.

A tablet intended for administration between the cheek and gum of the oral cavity. The active and/or inert ing redient(s) are usually absorbed through the oral mucosa and designed to be released slowly over a period of time. 